\title{
Proceeding
}

8th INSHS International Christmas Sport Scientific Conference, 5-7 December 2013. International Network of Sport and Health

Science. Szombathely, Hungary

\section{Physical activity as a determinant of diseases, back and joint pains in adult Czech population}

\author{
MICHALEK JOSEF , SEBERA MARTIN, SEDLACEK JAROMIR \\ Faculty of Sport Studies, Masaryk University, address: Kamenice 753/5, Brno, 62500 Czech Republic
}

\begin{abstract}
Josef, M., Martin, S. \& Jaromir, S. (2014). Physical activity as a determinant of diseases, back and joint pains in adult Czech population. J. Hum. Sport Exerc., 9(Proc1), pp.S429-S435. In this contribution it was shown that the Czech adult population has a relationship between selected kinds of individual physical activity and civilization diseases (smoking and alcohol consumption), back and join pains. In this research is involved 5862 adult (over 18 years of age) Czech people of both sexes. Watched parameters were gained by questionnaire (totally 19 questions) from which we are discussing an influence of sport practising (yes or not), character of the work (physical, physical and sedentary, sedentary or do not work) and kind of transportation to work (walking, biking, public transport, car or does not travel) on smoking, alcohol consumption, back and joints pains. Results demonstrated that over $72 \%$ of Czech adult population do not practise any sport. There were found only slight differences between watched parameters (smoking, alcohol consumption, back and joints pains) and those who are physically active or inactive. Back pains have over $70 \%$ of people, more often those not sporting. Join pains have about $55 \%$ and there are not any significant differences among groups. Very negative effects would be expected because of alcohol consumption - over $80 \%$ answered 'yes I take alcoholic drinks'; more positive seems to be parameter smoking, about $22 \%$ of the sports group were practising smokers, while among non sporting it was about $32 \%$. The parameter 'character of the work' does not show great differences; those who work physically smoke the least, those who do not work drink alcohol less like others. Also parameter transportation to work does not show any great differences; only those who use bike have significantly lower joints pains.

Presented results are part of The project "Creating a research team for the purpose of determining the level of physical activity (inactivity) in selected age groups of the population of men and women in the Czech Republic" (CZ.1.07/2.3.00/20.0044) is financed by the European Social Fund and the state budget of the Czech Republic. Key words: MOVEMENT ACTIVITY - INACTIVITY, ADULT POPULATION, SMOKING, ALCOHOLIC CONSUMPTION, BACK AND JOINT PAINS
\end{abstract}

Corresponding author. Faculty of Sport Studies, Masaryk University, Kamenice 753/5, Brno, 62500 Czech Republic.

E-mail: jaromir.sedlacek47@gmail.com

8th INSHS International Christmas Sport Scientific Conference, 5-7 December 2013. International Network of Sport and

Health Science. Szombathely, Hungary.

JOURNAL OF HUMAN SPORT \& EXERCISE ISSN 1988-5202

(c) Faculty of Education. University of Alicante

doi:10.14198/jhse.2014.9.Proc1.29

VOLUME 9 | Proc1 | 2014 | S429 


\section{INTRODUCTION}

In present society we meet more and more often with various health problems and civilisation diseases. In the contribution we aim at back and join pains like health problems by them suffers majority of present adult population. Back and joint pains belong to very often and unpleasent manifestations of men movement apparatus. The most often courses of pains of back can be seen in permanent disbalance of body position, where part of muscles is overloaded and shortened and another part is weakened and from this lost off balance results pains. There may be many reasons these back and joints pains, but the most often stated are sedentary way of life, lack of physical activity and obesity or overweight (Cacek, 2012; Kunesova, 2006).

Among civilisation diseases that are widely spread belong and alcohol and drogs consumption in which is Czech Republic according EU statistics one of the leading (in negative sence) countries (Hrcka et al., 2006). In 2009 the average alcohol consumption of alcohol in Czech Republic was 16,61 I per person; this is the highest consumption in EU (Anderson, 2012). Alcohol consumption started accelerate in 90-ies in of the last century. Similarly started negative trends in the alcohol consumption and drunk occurance among children and youths. This trend is in the contrast with the development in West European countries and in Poland, too, where alcohol consumption decreased or was stabilized (Andrlová, 2012).

Research held in 2011 shows that $29,1 \%$ adult citizens (15 - 64 years) in Czech Republic smoked. There is higher rate of smokers among singles and divorced. There was also proved that higher rate of smokers is among tranees, while university educated people smoke rarely (Sovinová et al., 2012).

\section{Objectives}

The aim of this research is to find the state of Czech adult population (over 18 years) in smoking, alcohol consumption, back and joint pains with regard to their movement activity.

\section{MATERIAL AND METHODS}

Evaluation of population characteristics were done by quetionnaire. There were involved 5862 Czech adult people (3023 female and 2829 males). Totally the questionnaire had 19 questions from which we work with these parameters: back pains (BP), joint pains (JP), alcohol consumption (AC) and smoking (SM), sex (female - male), regular movement activity resp. sport practising (yes - not), type of transport to work (walk, bike, public transport, car, none transport) and type of work (physical, sedentary, physical and sedentary, unemploed). Gained results were proseed by fundamental statistic and graphical methods. Statistical significance differences among parameters were evaluated on $5 \%$ statistical level.

\section{RESULTS AND DISCUSSION}

Majority of Czech adult population do not practise movement activity regularly (over 73\%); worse situation is among females from them only about $22 \%$ state that practise sports regularly (Table 1 ).

Over $73 \%$ of respondents stay that they have back pains. Again the situation is slightly worse among females. Those who are practising sport have less back pains (Table 2, fig 1). Differences between those with regular sport activity and without it are statistically significant $(p<0,05)$. 
Table 1. Recreational sport practice with regard of sex

\begin{tabular}{cccc}
\hline Sex & YES & NO & TOTAL \\
\hline Females & $682 / 22,55 \%$ & $2342 / 77,45 \%$ & 3024 \\
Males & $889 / 31,36 \%$ & $1946 / 68,64 \%$ & 2835 \\
Total & $1571 / 26,81 \%$ & $4288 / 73,18 \%$ & 5859 \\
\hline
\end{tabular}

Table 2. Back pains with regard of sex

\begin{tabular}{cccc}
\hline Sex & YES & NO & TOTAL \\
\hline Females & $2291 / 75,64 \%$ & $738 / 24,36 \%$ & 3026 \\
Males & $2024 / 71,24 \%$ & $817 / 28,76 \%$ & 2841 \\
Total & $4315 / 73,51 \%$ & $1555 / 26,49 \%$ & 5870 \\
\hline
\end{tabular}

Table 3. Joint paints with regard of sex

\begin{tabular}{cccc}
\hline Sex & YES & NO & TOTAL \\
\hline Females & $1642 / 54,25 \%$ & $1385 / 45,75 \%$ & 3027 \\
Males & $1582 / 55,65 \%$ & $1262 / 44,37 \%$ & 2844 \\
Total & $3224 / 54,91 \%$ & $2647 / 45,08 \%$ & 5871 \\
\hline
\end{tabular}

Table 4. Smoking with regard of sex

\begin{tabular}{cccc}
\hline Sex & YES & NO & TOTAL \\
\hline Females & $752 / 24,80 \%$ & $2280 / 75,20 \%$ & 3032 \\
Males & $97534,29 \%$ & $1868 / 65,71 \%$ & 2843 \\
Total & $1727 / 29,39 \%$ & $4148 / 70,61 \%$ & 5875 \\
\hline
\end{tabular}

Table 5. Alcohol consumption with regard of sex

\begin{tabular}{ccccc}
\hline Sex & NEVER & SOMETIMES & REGULARLY & TOTAL \\
\hline Females & $662 / 21,90 \%$ & $2279 / 75,39 \%$ & $82 / 2,71 \%$ & 3023 \\
Males & $400 / 14,09 \%$ & $2170 / 76,44 \%$ & $269 / 9,48 \%$ & 2839 \\
Total & $1062 / 18,11 \%$ & $4449 / 75,89 \%$ & $351 / 5,98 \%$ & 5862 \\
\hline
\end{tabular}

Joints pains have $55 \%$ of population. Values of males and females are near the same (Table 3, fig 2). Again those who practice sport have better results and differences are statistically significant $(p<0,05)$.

In present Czech adult population is near $30 \%$ of smokers, more often smoke males (Table 4). Those who practice sport again smoke less and differences are significant $(p<0,05)$, (fig 3$)$.

Parameter alcohol consumption confirms that Czech adult population drinks too much. Over $80 \%$ drinks either sometimes or regularly (Table 5). Again those who practice sport drink alcohol less, though the differences are not so clear (fig 4). 
On the fig 5 can be seen that those who have either sedentary or are unemployed practise sports far less comparing those whose type of work is either physical or combination of physical and sedentary.

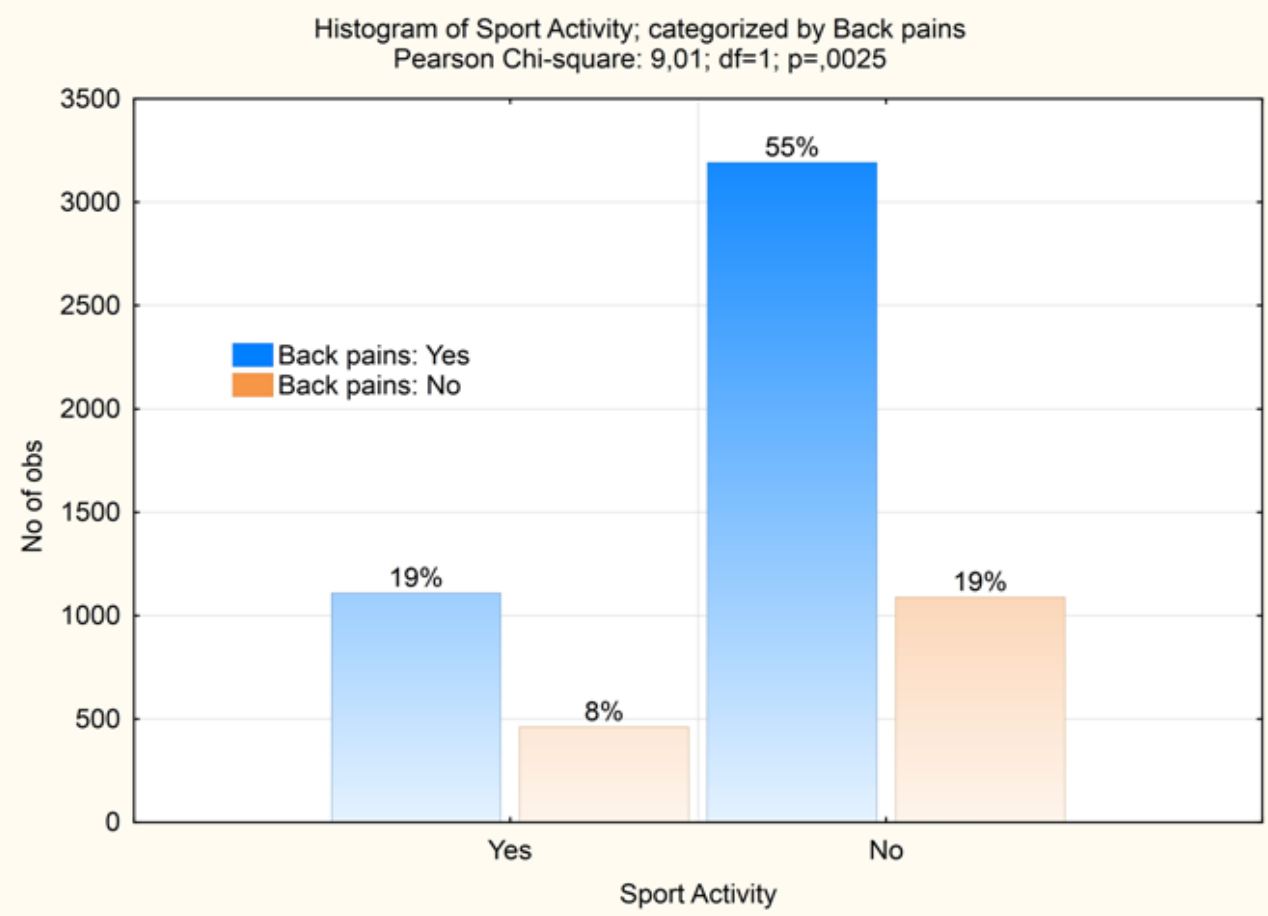

Figure 1. Back Pains distribution in Czech adult population with regard of sport practicing

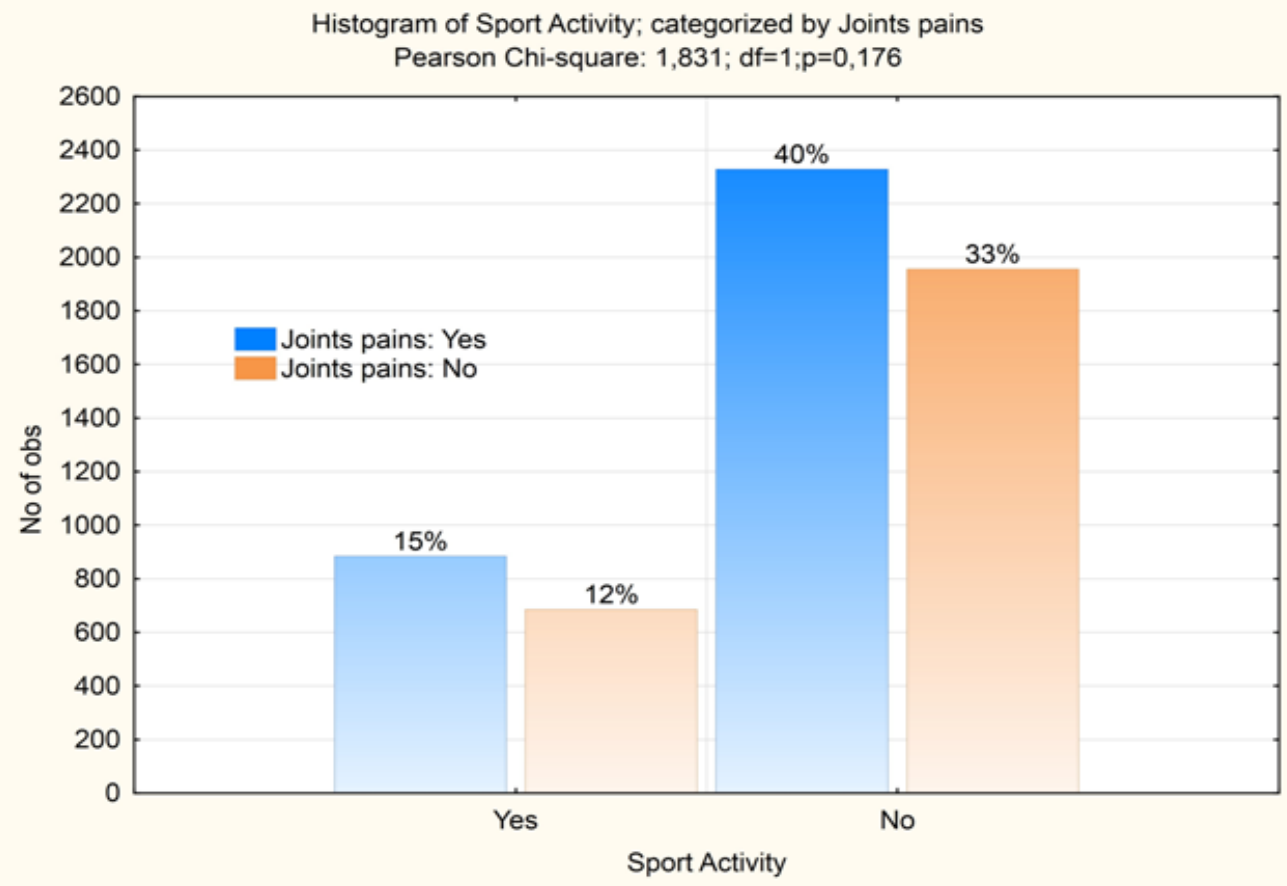

Figure 2. Joint pains distribution in Czech adult population with regard of sport practicing 


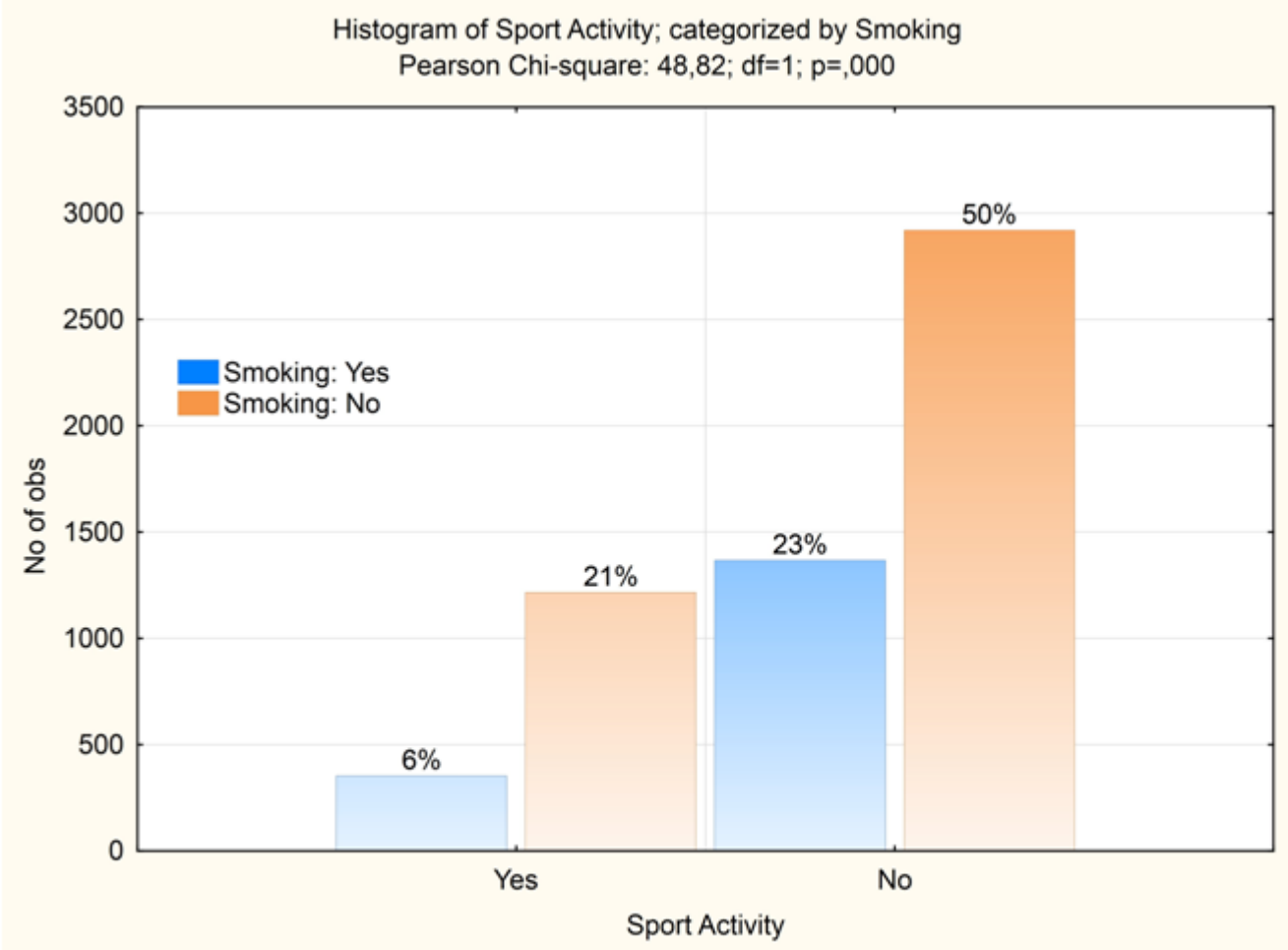

Figure 3. Smoking distribution in Czech adult population with regard of sport practicing

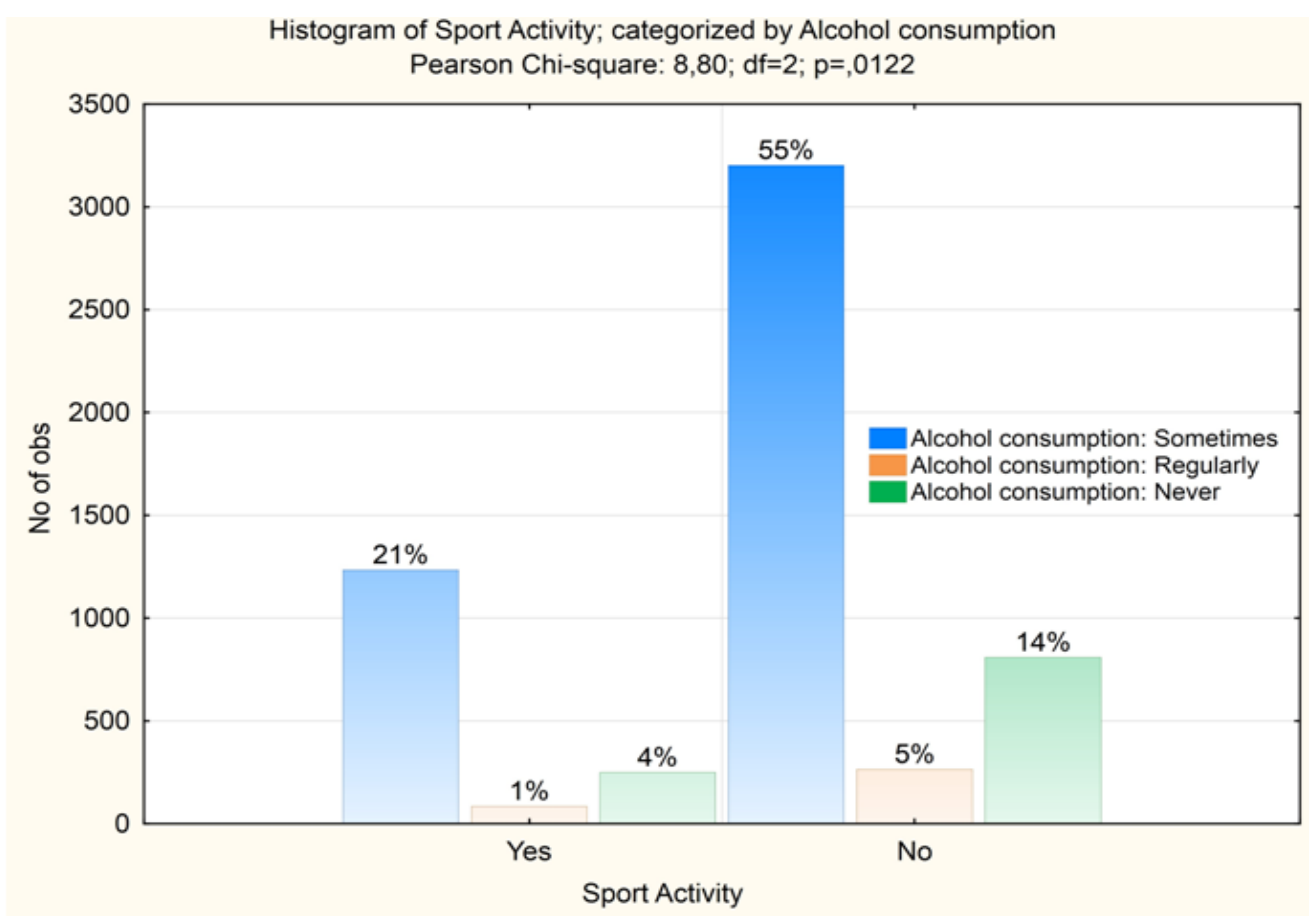

Figure 4. Alcohol consumption distribution in Czech adult population with regard of sport practicing 


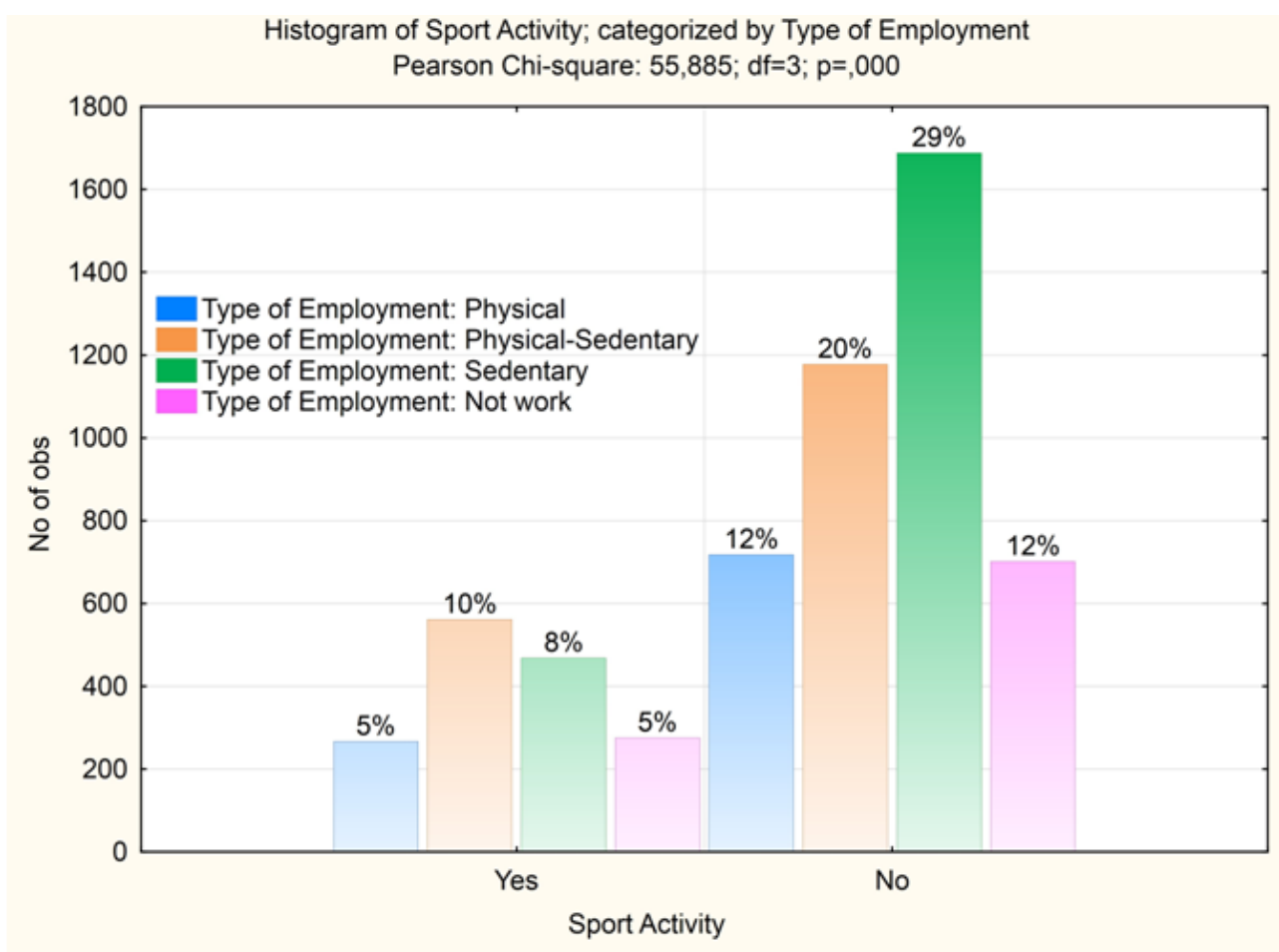

Figure 5. Type of employment distribution in Czech adult population with regard of sport practicing

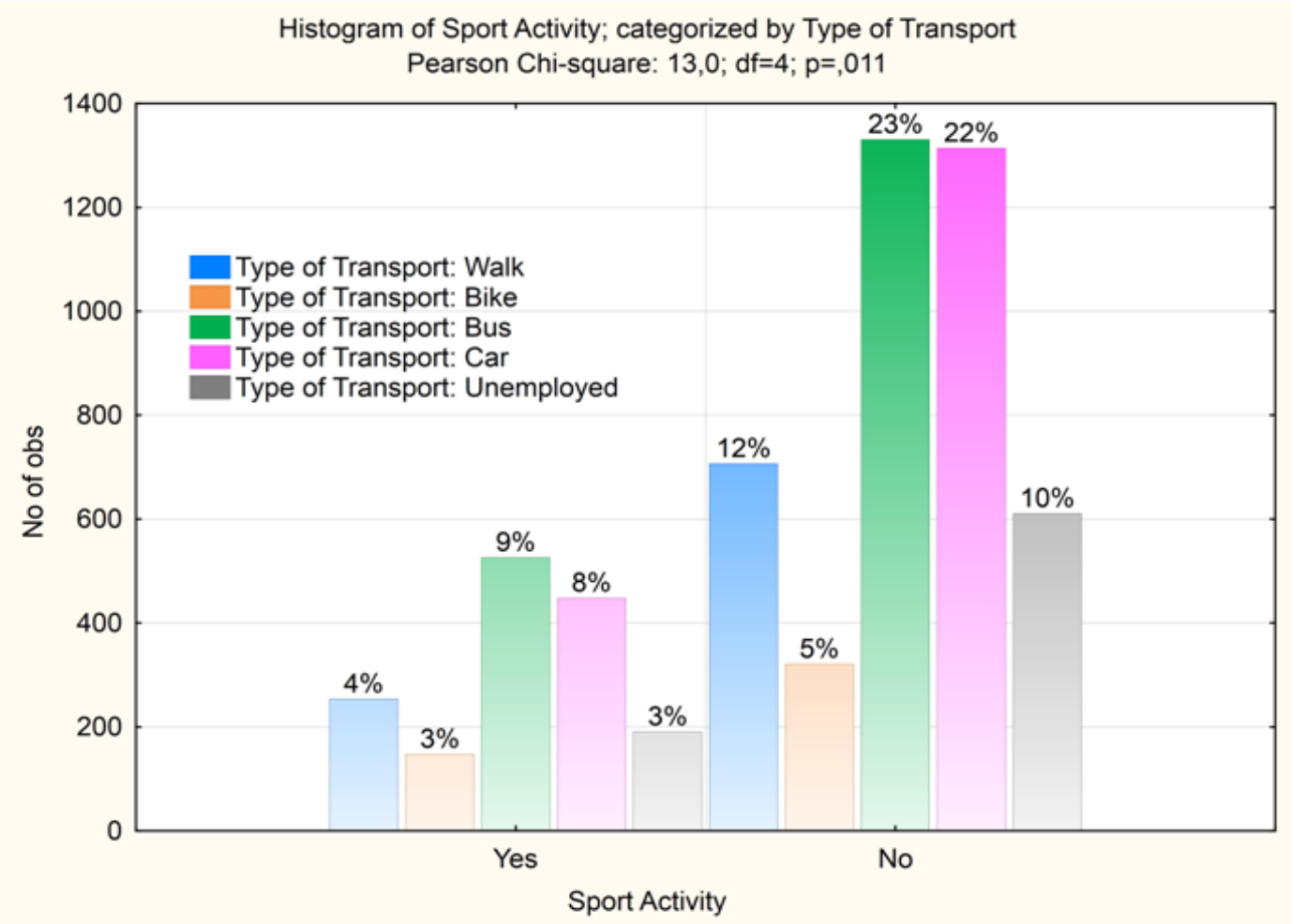

Figure 6. Distribution of type of transport to occupation in Czech adult population with regard of sport practicing 
On the fig 6 is seen the situation with types of transport to work. It seems clear that active types (walk and bike) influence also the sport activity that is far often like it is in case of not active means of transport to work $(p<0,05)$.

\section{CONCLUSIONS}

1. Czech adult population does not practice sport in adequate (recommended) level.

2. Majority of population have back and joint pains. Those who practice sport have significantly less problems.

3. Smokers are "only" about 30\%; this parameter seems relatively positive. Often smoke those who are less physically active.

4. Parameter alcohol consumption confirms negative situation of Czech adult population Differences between sport practising and not practising are not significant; this can be considered like surprising.

5. Active kinds of work and transport to work positively influence also other sport activity in leisure time. Differences are statistically significant $(p<0,05)$.

\section{REFERENCES}

1. Anderson, P., Møller, L. \& Galea, G. (2012). Alcohol in the European Union - consumption, harm and policy approaches. WHO Regional Office for Europe Copenhagen, Denmark.

2. Andrlová, I. (2012). Faktory ovlivňující konzumaci alkoholu v populaci. ČR. Brno.

3. Cacek, J. et al., (2012). Obesity as an indicator of fitness of different age groups of men of the Czech. Republic.Gymnasium,13(2), pp.78-84.

4. Hrcka, J., Krska, P. \& Mikusova, M. (2006). Afinita 16-17 ročných žiakov ku športovaniu a ich skúsenost's nelegálnymi drogami v banskobystrickom regióne. Ružomberok: PF KU.

5. Kunesová, M. (2006). Životní styl a obezita- longitudinální epidemiologická studie prevalence obezity v ČR. Česká lékařská společnost ČSL JEP, Česká obezitologická společnost (Life style and obesity - longitudinal epidemiologic study of obesity prevalence in Czech Republic). Stem/Mark, a.s.: Praha.

6. Sovinova, H., Sadilek, P. \& Csemy, L. (2012). Vyvoj prevalence kuractvi. Statni zdravotni ustav. CR: http://www.szu.cz/uploads/documents/czzp/zavislosti/koureni/zprava-kuractvi-2011.pdf

The project "Creating a research team for the purpose of determining the level of physical activity (inactivity) in selected age groups of the population of men and women in the Czech Republic" (CZ.1.07/2.3.00/20.0044) is financed by the European Social Fund and the state budget of the Czech Republic. 